\title{
Effect of Lockdown on HCHO and Trace Gases over India during March 2020
}

\section{Aerosol and Air Quality Research}

Special Issue:

Special Issue on COVID-19 Aerosol Drivers, Impacts and Mitigation (XII)

\author{
Akshansha Chauhan ${ }^{1}$, Ramesh P. Singh ${ }^{2 *}$ \\ ${ }^{1}$ Center for Space and Remote Sensing Research, National Central University, Taoyuan 32001, \\ Taiwan \\ ${ }^{2}$ School of Life and Environmental Sciences, Schmid College of Science and Technology, \\ Chapman University, Orange, CA-92866, USA
}

COVID-19 is one of the deadly Epidemics that has impacted people living in more than 200 countries. In order to mitigate the impact of COVID-19, India observed total lockdown in the first phase for a period of 21 days (24 March-13 May 2020), so that social distancing is maintained. However, this sudden decision severely affected the normal life of people. The air quality improved due to lockdown, some relaxation was given in different cities and within some areas in the city where the people were not affected by COVID-19. In this paper, we discuss results of detailed analysis of trace gases $\left(\mathrm{HCHO}, \mathrm{NO}_{2}, \mathrm{SO}_{2}, \mathrm{CH}_{4}, \mathrm{CO}\right.$ and $\mathrm{O}_{3}$ ) and particulate matter concentration using satellite and ground data in major metropolitan cities of India during 10-31 March, 2020 and compared with the same period in the year 2019, to study the impact of total lockdown. Our analysis suggests, pronounced qualitative changes in $\mathrm{HCHO}, \mathrm{NO}_{2}, \mathrm{SO}_{2}, \mathrm{CH}_{4}, \mathrm{CO}$, $\mathrm{O}_{3}$ and $\mathrm{PM}_{2.5}$ concentration during complete lockdown period in the month of March 2020. We did not consider the period after 31 March 2020 to avoid influence of anthropogenic sources since the Government made relaxation in the lockdown periods after 31 March 2020.

Keywords: COVID-19, Trace gases, $\mathrm{PM}_{2.5}$, Air quality, $\mathrm{HCHO}$, India

\section{INTRODUCTION}

The COVID-19 is now known as one of the deadly epidemics of Modern Era (https://www.who. int/news-room/detail/27-04-2020-who-timeline--covid-19). About 37,113,410 people suffer with this epidemic and about 1,072,712 killed in the world (https://www.worldometers.info/cor onavirus/), still the number is increasing day by day. The COVID-19 started from Wuhan city, capital of Hubei province of China (Chauhan and Singh, 2020; Rajbhandari et al., 2020; Singh and Chauhan, 2020; Wang et al., 2020a) in the month of December 2019 and the world came to know about this deadly virus in the beginning of 2020. With the increase in the COVID-19 cases, the whole world is moving through a very distressing situation (Wang et al., 2020b, c).

Few cases were reported in India in the beginning of January 2020 which was associated with the Italian tourists and few Indians returning to India from abroad. Looking at the serious nature of the COVID-19, Government of India observed Janata (People's) curfew on 22 March 2020, after its success, the Government of India immediately implemented total lockdown as of 24 March 2020 for 21 days in the first phase (Chauhan and Singh, 2020; Singh and Chauhan, 2020). During this lockdown, improvement in air quality was observed in India. Efforts were made to use ground air quality $\left(\mathrm{PM}_{2.5}, \mathrm{PM}_{10}, \mathrm{CO}, \mathrm{NO}_{2}, \mathrm{SO}_{2}, \mathrm{O}_{3}\right)$ from the Central Pollution Control Board (CPCB) data and improvement in air quality in different cities, different states and in whole of India, was observed (Mittal et al., 2012; Kumari and Toshniwal, 2020; Mahato et al., 2020; Selvam et al., 2020; Sharma et al., 2020). Chauhan and Singh (2020) and Singh and Chauhan (2020) used air quality data from the sensors deployed in five U.S. embassies in India, the data are freely available through the U.S. EPA (Environmental Protection Agency), a pronounced improvement in air quality was observed. 
In the present study, we have analysed trace and greenhouse gases over India, and major metropolitan cities in India during March 2019 and 2020 using satellite data. During lockdown periods, the major anthropogenic sources were minimum, so we considered analysis of these gases to get a clear picture of the atmospheric chemistry during complete lockdown period. We have considered an average of 10-21 March prior and during lockdown periods 22-31 March 2020 and compared with the same time periods for the year 2019. We did not consider the period after 31 March 2020 to avoid influence of anthropogenic sources since the Government made relaxation in the lockdown periods after 31 March 2020.

\subsection{Lockdown in India during COVID-19}

During COVID-19, partial to total lockdown was observed in some of the severely affected cities/states of various countries around the world, in India, a complete lockdown was strictly followed. Wang et al. (2020d) have shown a decline in $\mathrm{PM}_{2.5}$ concentration in major cities of China during lockdown due to reduction in traffic on the roads. Chauhan and Singh (2020) observed decline in $\mathrm{PM}_{2.5}$ over major cities of the world and major cities in India where US embassies are located (Singh and Chauhan, 2020). Recently, Sharma et al. (2020) have used Central Pollution Control Board data and studied the impact of air quality for the periods 15 March-14 April 2020. Lockdown affected all social and economic activities in India and even the river quality of water has been found to be cleaner (Garg et al., 2020).

In India, beginning from April, each year, wheat, and sugarcane crops are harvested, and farmers start making sugarcane by-products, these are the sources of atmospheric pollution and cause poor air quality. Government of India exempted farmers in the villages during the lockdown period after first week of April 2020, for the harvesting of crops. Emergency services and telecom sectors were also exempted during the lockdown. Later, the lockdown was extended further until 3 May 2020 and beyond. Due to lockdown in India, most of the sources associated with the anthropogenic were completely stopped in the first phase. Even the trains and flights (domestic and international) were stopped. Pronounced decline in consumption of fossil fuel was noticed (https://www.businesstoday.in/sectors/energy/lockdown-impact-indian-fuel-consumption-drop60-in-april/story/401318.html). Due to improvement of air quality, visibility in many cities was improved significantly. Recently, Gupta et al. (2020) have analysed various kinds of weather data and predicted model for spread of COVID-19 in U.S. and India.

\subsection{Major Sources of Atmospheric Pollution}

The northern parts of India especially in the Indo-Gangetic Plain (IGP) is well known as one of the highly polluted and agriculturally productive regions in India. Delhi, capital of India, is located in the IGP which is known as one of the polluted cities in the world, compared to Beijing city in China (Zheng et al., 2017). The sources of pollution, seasonal variability and long term of pollutants are studied by many (Prasad and Singh, 2007; Mittal et al., 2012; Guttikunda et al., 2014; Singh, 2014; Arif et al., 2018; Sarkar et al., 2018a). Lockdown affected most of anthropogenic sources, but some sources remained functional even during lockdown, like, thermal power plants, biomass burning, brick kilns, sugar mills etc. In village, livestock and crop residue burning is quite common for the preparation of food (Smith et al., 1983; Ramachandra et al., 2015; Arif et al., 2018). Lockdown encouraged poor families to burn biomass in rural area so Government of India provided free Liquid Petroleum Gas (LPG) cylinders to economically challenged community under Ujjawala Gas Scheme (https://pib.gov.in/PressReleasePage.aspx?PRID=1614723). Crop residue burning is a major sources of air pollution in India during post-monsoon season in the Northern, Southern and Central parts of India (Mittal et al., 2009; Singh and Kaskaoutis, 2014; Chauhan and Singh, 2017; Sarkar et al., 2018a, b) and also some activities are observed during pre-monsoon months. This is one of the major sources of various trace gases such as $\mathrm{CO}_{2}, \mathrm{CO}, \mathrm{NO}_{\mathrm{x}}, \mathrm{CH}_{4}$, and $\mathrm{SO}_{2}$, and along with this it also emits un-burnt carbon into the atmosphere. According to Streets et al. (2003), CRB contributes approximately $0.37 \mathrm{Tg}$ of Sulphur dioxide, $1100 \mathrm{Tg}$ of $\mathrm{CO}_{2}, 3.1 \mathrm{Tg}$ of methane $\mathrm{CH}_{4}, 2.8 \mathrm{Tg}$ of $\mathrm{NO}_{x}$, and $67 \mathrm{Tg}$ of $\mathrm{CO}$. India is one of the second largest (25.2\%) contributors to the emission of non-methane Volatile organic compounds (NMVOCs) after China (35.2\%), from possible sources such as, residential combustion, increasing traffic emissions and growing industrial emissions (Li et al., 2014; Chutia et al., 2019). Volatile organic compounds (VOCs) are 
produced in the atmosphere from both natural and anthropogenic sources and play an important role in the atmospheric chemistry, air quality and climate (Seinfeld and Pandis, 2006; Chutia et al., 2019). Ghosh et al. (2015) carried out measurements in Kolkata and observed seasonal variations in $\mathrm{HCHO}$ and trace gases and observed very high influence of seasonal wind patterns. In the last three decades, the land use and land cover patterns have grown in the rural and urban areas that have enhanced the VOC emissions. High level of VOCs are from the megacities (Delhi, Mumbai, Kolkata) (Talapatra and Srivastava, 2011; Ghosh et al., 2015). The small petrochemical and coal processing industries, sewage plants and forest fires are the sources of $\mathrm{HCHO}$ and mixing ratio in the atmosphere (Dasgupta et al., 2005; Karar and Gupta, 2006; Ghosh et al., 2015). The people living in the cities having high $\mathrm{HCHO}$ and VOCs environment have higher risk of cancer especially in Kolkata (Majumdar et al., 2011).

In the north-eastern regions (NER) of India, often times forest fires occur during February and March, that cause poor air quality and atmospheric pollution (Badarinath et al., 2009). In this region, few part of the forest are burnt during March every year for preparation of monsoon crop (https://earthobservatory.nasa.gov/images/85500/fire-in-northeast-india). The agricultural activities, biomass-burning, crop residue burning, brick kilns, oil and gas fields significantly contribute to the atmospheric pollution and poor air quality (Sahu et al., 2015; Pathak et al., 2016; Gogoi et al., 2017). The atmosphere over the Bay of Bengal (BoB) region are polluted due to continental out flow from the industrial coastal and NER regions especially during winter season (Ojha et al., 2012; Kumar and Verma, 2016; Verma et al., 2017; Priyadharshini et al., 2018). Long range transport of dust from the Arabian Peninsula and the Thar desert impact the northern parts of India, especially the Indo-Gangetic Plains (IGP) during the pre-monsoon months. The westerly winds depending upon the wind speed, the dust air mass reaches even in the eastern parts of IGP and beyond affecting a large population, about 900 million people living in the region (Middleton, 1986; Bhattacharjee et al., 2007; Singh, 2014; Kumar et al., 2015; Priyadharshini et al., 2018, 2019; Sarkar et al., 2019).

Atmospheric chemistry plays important role in major atmospheric conditions that is responsible for climatic changes. Gases like $\mathrm{CH}_{4}, \mathrm{CO}, \mathrm{NO}_{2}+\mathrm{NO}_{x}, \mathrm{SO}_{2}, \mathrm{CO}_{2}, \mathrm{HCHO}$ etc. are important gases that play important role in atmosphere. Some of these gases, $\mathrm{CH}_{4}, \mathrm{CO}, \mathrm{NO}_{2}$ and $\mathrm{SO}_{2}$ are produced from the anthropogenic activities as a direct product and $\mathrm{HCHO}$ is one of the major intermediate products of $\mathrm{CH}_{4}$ cycle produced from various photochemical oxidation of hydrocarbons and higher aldehydes (Goldan et al., 2000; Singh et al., 2000; Miller et al., 2008). Compared to natural sources, anthropogenic sources cause emission of $\mathrm{HCHO}$ which can be harmful for the human beings (WHO, 1999; U.S. EPA, 2003; Dasgupta et al., 2005; Karar and Gupta, 2006). In atmosphere, the life span of $\mathrm{CH}_{4}$ is few years, $\mathrm{CO}$ in months, $\mathrm{SO}_{2}$ in weeks and $\mathrm{NO}_{2}$ in day but $\mathrm{HCHO}$ is life of few hours (Burkholder et al., 2015), that is decomposed into $\mathrm{CO}$ and $\mathrm{H}_{2}$ in the presence of sunlight. In urban atmosphere, $\mathrm{HCHO}$ reacts with $\mathrm{OH}$ and $\mathrm{HO}_{2}$. The night-time losses are slow, and it mainly reacts with nitrate radical. It plays a major role since it acts as a precursor for ozone in the atmosphere. Similarly, $\mathrm{CH}_{4}$ and $\mathrm{NO}_{2}$, together helps in formation of $\mathrm{CO}$ and are responsible for the formation of surface ozone. Surface ozone is greenhouse gas and can be a major threat to human health. These chemical reactions are as follows (Wallace and Hobbs, 2006; Zheng et al., 2017).

$$
\begin{aligned}
& \mathrm{OH}+\mathrm{CH}_{4}=\mathrm{H}_{2} \mathrm{O}+\mathrm{CH}_{3} \\
& \mathrm{OH}+\mathrm{CO}=\mathrm{H}+\mathrm{CO}_{2} \\
& \mathrm{OC}+\mathrm{CO}=\mathrm{H}_{2} \mathrm{O}+\mathrm{CH}_{3} \mathrm{CO}
\end{aligned}
$$

The radical $\mathrm{CH}_{3}, \mathrm{H}$ and $\mathrm{CH}_{3} \mathrm{CO}$ involved in reaction which converts $\mathrm{NO}$ to $\mathrm{NO}_{2}$ and regenerate $\mathrm{OH}$. During this reaction $\mathrm{HCHO}$ is also produced.

$$
\begin{aligned}
& \mathrm{CH}_{3}+\mathrm{O}_{2}=\mathrm{CH}_{3} \mathrm{O}_{2} \\
& \mathrm{CH}_{3} \mathrm{O}_{2}+\mathrm{NO}=\mathrm{CH}_{3} \mathrm{O}+\mathrm{NO}_{2} \\
& \mathrm{CH}_{3} \mathrm{O}+\mathrm{O}_{2}=\mathrm{HCHO}+\mathrm{HO}_{2}
\end{aligned}
$$




$$
\begin{aligned}
& \mathrm{HO}_{2}+\mathrm{NO}=\mathrm{NO}_{2}+\mathrm{OH} \\
& \text { Further, } \\
& \mathrm{HCHO}+h \mathrm{O}=\mathrm{H}+\mathrm{HCO} \\
& \mathrm{HCO}+\mathrm{O}_{2}=\mathrm{HO}_{2}+\mathrm{CO}
\end{aligned}
$$

together with $\mathrm{CO}$ and $\mathrm{NO}$ is responsible for the formation of ozone at ground level.

$$
\begin{aligned}
& \mathrm{OH}+\mathrm{CO}+\mathrm{O}_{2}=\mathrm{HO}_{2}+\mathrm{CO}_{2} \\
& \mathrm{HO}_{2}+\mathrm{NO}=\mathrm{OH}+\mathrm{NO}_{2} \\
& \mathrm{NO}_{2}+h v=\mathrm{NO}+\mathrm{O} \\
& \mathrm{O}+\mathrm{O}_{2}+\mathrm{M}=\mathrm{O}_{3}+\mathrm{M}
\end{aligned}
$$

The atmospheric chemistry changes in the presence of sun, and the surface ozone is formed.

\subsection{Data Used}

In the present study, we have carried out analysis of total column formaldehyde ( $\mathrm{HCHO})$, nitrogen dioxide $\left(\mathrm{NO}_{2}\right)$, methane $\left(\mathrm{CH}_{4}\right)$, carbon monoxide $(\mathrm{CO})$, total column sulphur dioxide $\left(\mathrm{SO}_{2}\right)$ and ozone $\left(\mathrm{O}_{3}\right)$ using various satellite data.

\subsection{Meteorological Data}

We have carried out analysis of the meteorological parameters (air temperature, station pressure, and relative humidity) using Airport station data available through https://rp5.ru/Wea ther_in_the_world.

\subsection{AIRS Data}

We have considered methane $\left(\mathrm{CH}_{4}\right)$, carbon monoxide $(\mathrm{CO})$ and ozone $\left(\mathrm{O}_{3}\right)$ gas emissions data observed from the Atmospheric Infrared Sounder (AIRS) for detailed analysis. This data is available at different pressure levels and we have used data at pressure level $925 \mathrm{hPa}$ close to the earth's surface, average of daytime (ascending mode) and night time (descending mode) data for better temporal coverage to avoid gap in data during day or night time. Satellite data (spatial resolution of $1^{\circ} \times 1^{\circ}$ ) is taken through NASA Giovanni portal (https://giovanni.gsfc.nasa.gov/giovanni/).

\subsection{OMI Data}

The Ozone Monitoring Instrument (OMI) provides information of atmospheric aerosols properties. This instrument provides information about various atmospheric gases, $\mathrm{NO}_{2}$, ozone and $\mathrm{SO}_{2}$. This satellite is part of NASA Aura satellite mission which is an A-train satellite. The analysis of atmospheric concentration of $\mathrm{HCHO}$, tropospheric $\mathrm{NO}_{2}$ and column amount $\mathrm{SO}_{2}$ (Planetary Boundary Layer) were carried out using OMI AURA data. The resolution of tropospheric $\mathrm{NO}_{2}$ and column amount $\mathrm{SO}_{2}$ is $0.25^{\circ} \times 0.25^{\circ}$ and for $\mathrm{HCHO}$ the resolution of data is $0.1^{\circ} \times 0.1^{\circ}$ and is taken from NASA Giovanni portal.

\subsection{PM 2.5 Data}

U.S. Environmental Protection Agency (U.S. EPA) provides air quality data of various ground stations across the globe. Air quality $\left(\mathrm{PM}_{2.5}\right)$ data of various cities outside U.S. is available through U.S. EPA AirNow platform (https://www.airnow.gov/international/us-embassies-and-consulates/). The air quality sensors are located in five U.S. Embassies in India, Delhi, Mumbai, Chennai, Hyderabad, and Kolkata (Fig. 1, coordinates of U.S. Embassies are given in Table 1).

For satellite data, we have considered five $1^{\circ} \times 1^{\circ}$ boxes (coordinates are given in Table 2 ) over U.S. embassies in India. 


\section{RESULTS AND DISCUSSION}

\subsection{Meteorological Parameters of Major Cities}

Fig. 2 shows the temporal variations of meteorological parameters (a) air temperature, (b) relative humidity, and (c) station level pressure. A gradual rise in temperature is observed at all five

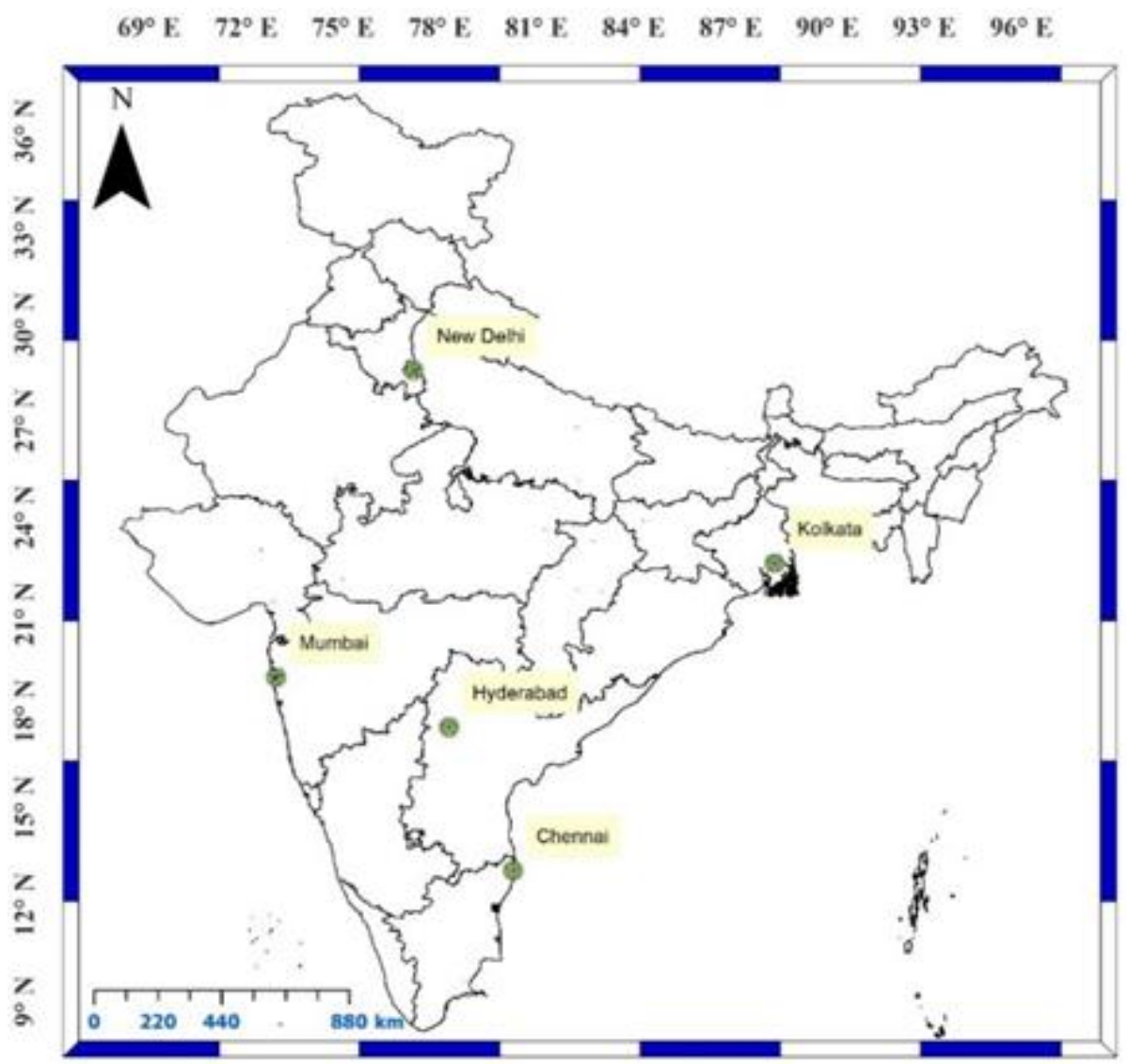

Fig. 1. Location of five embassies in India (green dots).

Table 1. Coordinates of Bounding Boxes $\left(1^{\circ} \times 1^{\circ}\right)$ over five US Embassies.

\begin{tabular}{lllll}
\hline Station Name & West & South & East & North \\
\hline Delhi $(28.57,77.18)$ & 76.68 & 28.07 & 77.68 & 29.07 \\
Hyderabad $(17.51,78.28)$ & 77.78 & 17.01 & 78.78 & 18.01 \\
Chennai $(13.06,80.16)$ & 79.76 & 12.56 & 80.76 & 13.56 \\
Mumbai $(19.05,72.92)$ & 72.42 & 18.55 & 73.42 & 19.55 \\
Kolkata $(22.58,88.36)$ & 87.86 & 22.08 & 88.86 & 23.08 \\
\hline
\end{tabular}

Table 2. Coordinates of Bounding Boxes $\left(1^{\circ} \times 1^{\circ}\right)$ over five US Embassies for satellite data.

\begin{tabular}{llll}
\hline Parameter & Source & Spatial Resolution & Temporal Resolution \\
\hline $\mathrm{CH}_{4}$ Concentration at $925 \mathrm{hPa}$ & AIRS Satellite Data & $1^{\circ} \times 1^{\circ}$ & 1 Day \\
$\mathrm{CO}$ Concentration at $925 \mathrm{hPa}$ & AIRS Satellite Data & $1^{\circ} \times 1^{\circ}$ & 1 Day \\
$\mathrm{O}_{3}$ Concentration at $925 \mathrm{hPa}$ & AIRS Satellite Data & $1^{\circ} \times 1^{\circ}$ & 1 Day \\
Tropospheric NO$_{2}$ & OMI Satellite Data & $0.25^{\circ} \times 0.25^{\circ}$ & 1 Day \\
Column Amount $\mathrm{SO}_{2}(\mathrm{PBL})$ & OMI Satellite Data & $0.25^{\circ} \times 0.25^{\circ}$ & 1 Day \\
Column Amount $\mathrm{HCHO}$ & OMI Satellite Data & $0.1^{\circ} \times 0.1^{\circ}$ & 1 Day \\
Concentration of $\mathrm{PM}_{2.5}$ & US EPA Ground Observations & None & 1 hour \\
\hline
\end{tabular}




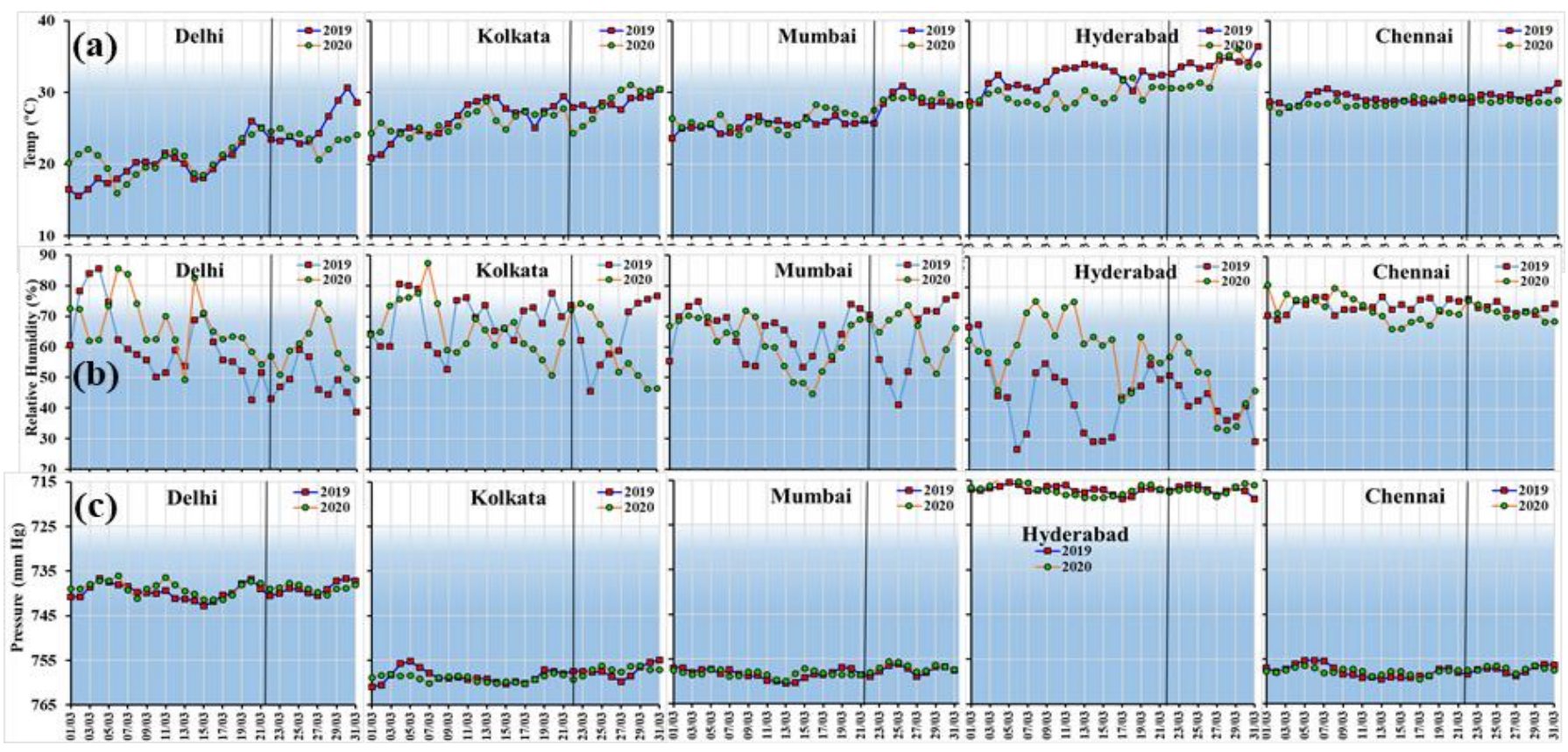

Fig. 2. Temporal variations of (a) Air Temperature, (b) Relative Humidity and (c) Station Level Pressure at five locations during March 2019 and 2020, vertical solid black line is the start date of total lockdown.

locations (Delhi, Kolkata, Mumbai, Hyderabad, and Chennai) during March 2019 and 2020. At Delhi, the average temperature during March 2019 and 2020 , respectively, was $21.65^{\circ} \mathrm{C}$ and $21.54^{\circ} \mathrm{C}$. We observed small decline in the average temperature in 2020 after the $22 \mathrm{March}$ and hence the average temperature during 22 March to 31 March 2020 is lower during the same period compared in the year 2019. No major changes are observed with air pressure during 2019 and 2020 over Delhi. The average relative humidity during March 2020 was observed to be higher over Delhi compared to 2019. In Kolkata, no major changes are observed in air temperature, however, the relative humidity is found to be lower over Kolkata during 2020 compared to 2019. Similar changes are also observed over Mumbai, but no major changes are observed in the average temperature at different pressure levels. A decline is found in relative humidity (more than $10 \%$ ) after 25 March 2020. In Hyderabad, $2^{\circ} \mathrm{C}$ decline in air temperature is observed in 2020 compared to 2019 , however, no changes are observed at different pressure levels. The average relative humidity is observed to be higher in the month of March 2020 during lockdown periods. In Chennai, no major changes are observed in the air temperature, and relative humidity at different pressure levels. The air temperature and relative humidity are observed to be higher, likely due to proximity with the Bay of Bengal. The relative humidity shows variations in 2020 compared to 2019. In 2019, RH shows enhancement over Mumbai and Kolkata after 22 March, a decline in $\mathrm{RH}$ is observed during lockdown period in 2020 (Fig. 2(b))

\subsection{Daily Variations of $\mathrm{PM}_{2.5}$ during March 2019 and 2020}

Fig. 3 shows daily variations of PM2.5 over Delhi, Hyderabad, Chennai, Mumbai, and Kolkata in the month of March 2019 and 2020. The $\mathrm{PM}_{2.5}$ concentrations is observed to be highest in Delhi $\left(62.98 \mu \mathrm{g} \mathrm{m}^{-3}\right)$, followed by Kolkata $\left(61.99 \mu \mathrm{g} \mathrm{m}^{-3}\right)$, Mumbai $\left(49.71 \mu \mathrm{g} \mathrm{m}^{-3}\right)$, and Hyderabad $\left(37.54 \mu \mathrm{g} \mathrm{m}^{-3}\right.$ ) during March, whereas, in Chennai PM 2.5 is lowest $\left(20.57 \mu \mathrm{g} \mathrm{m}^{-3}\right.$ ) (Table 3). In comparison to 2019, the average $\mathrm{PM}_{2.5}$ concentration is lower in almost all cities during 2020 except in Chennai. In Delhi, Hyderabad, Mumbai, and Kolkata, a pronounced decline in $\mathrm{PM}_{2.5}$ concentrations is observed during lockdown period (after 25 March) during 2020. In Chennai, $\mathrm{PM}_{2.5}$ is higher in some days in the month of March 2020, the average concentration prior and during the lockdown show a decline in all the five cities. The concentrations of $\mathrm{PM}_{2.5}$ depend on the local emissions, depending on the airmass reaching at these five locations. The air quality in Delhi and Kolkata located in the Indo-Gangetic plains (IGP) is generally poor (Sarkar et al., 2018a, 2019; Chauhan and Singh, 2020; Singh and Chauhan, 2020). 


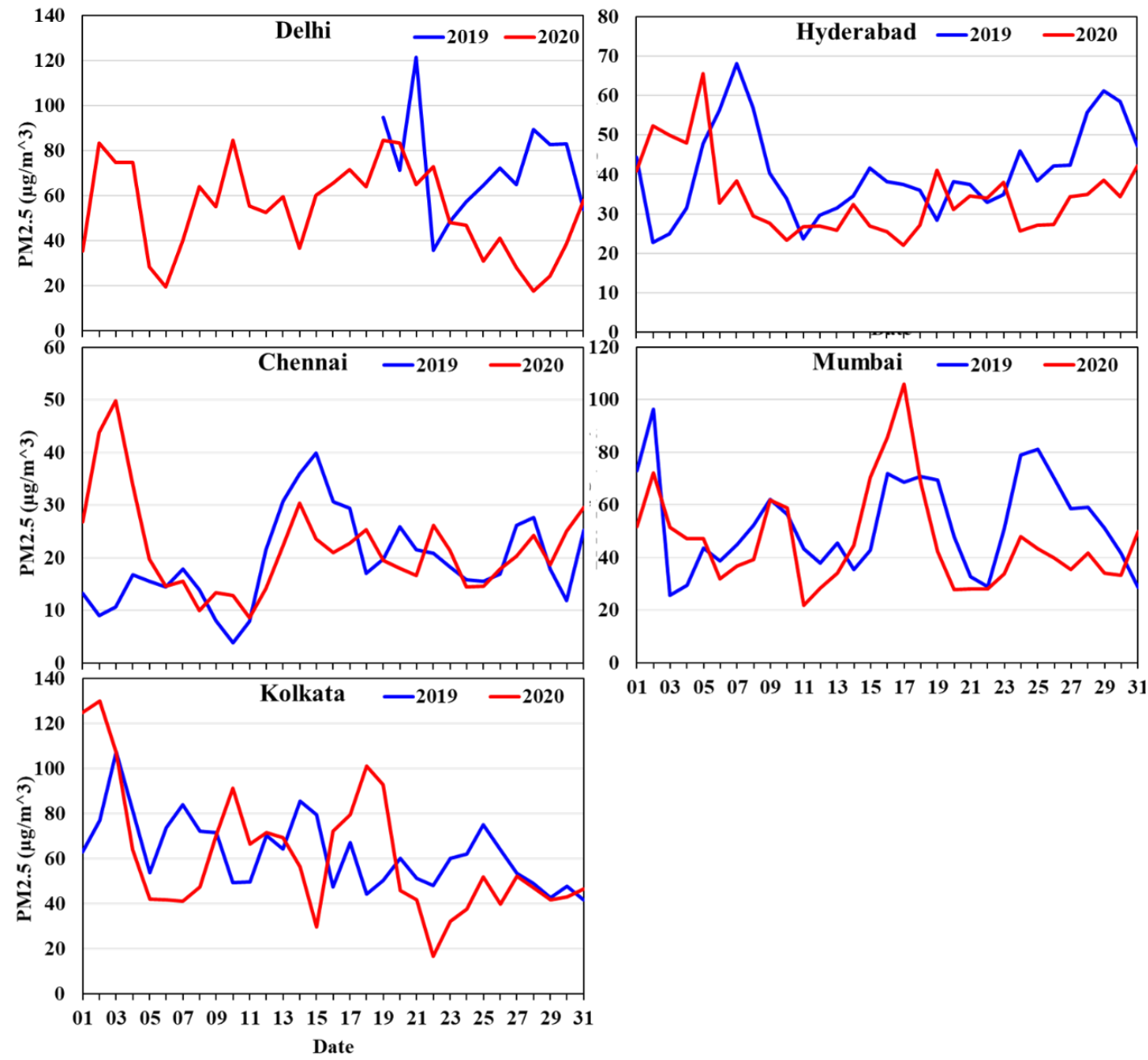

Fig. 3. Daily variations of $\mathrm{PM}_{2.5}$ in the month of March 2019 (blue line) and 2020 (red line) at five locations.

The westerly winds influence PM2.5 concentrations in Delhi and Kolkata and the southerly and south-easterly winds also impact $\mathrm{PM}_{2.5}$ of Kolkata. The $\mathrm{PM}_{2.5}$ in Delhi and Kolkata is also affected from long range transport of airmass associated with westerly winds and often due to western disturbances especially in the month of March (Dimri and Chevuturi, 2016). Depending upon the intensity of western disturbances the weather conditions over Delhi and beyond are impacted even up to Kolkata.

In Mumbai and Hyderabad, air quality is mainly affected from local traffic and from airmass reaching from different directions depending upon the wind directions. The $\mathrm{PM}_{2.5}$ concentrations in Chennai is variable due to its proximity to the ocean where airmass reaches from all the directions. The $\mathrm{PM}_{2.5}$ concentration is of dynamic in nature depends on the wind directions and moistures from the coastal areas. Recently, Singh and Chauhan (2020) have discussed decline in air quality at these five locations in view of the airmass reaching at these locations from different directions and have discussed the change in sources of airmass influencing $\mathrm{PM}_{2.5}$ concentrations. The decline in $\mathrm{PM}_{2.5}$ compared to 2019 during pre and during lockdown periods is given in Table 3.

\subsection{Spatial Variations of HCHO over India}

During lockdown period 22-31 March 2020, concentration of various trace gases in atmosphere and other chemical species were reduced due to closure of industrial, vehicular and anthropogenic activities. Fig. 4 shows the average HCHO concentration over India during (a) 10-21 March 2019; (b) 10-21 March 2020; (c) 22-31 March 2019 and (d) 22-31 March 2020. In many parts of India, enhancement in $\mathrm{HCHO}$ concentration was observed during 22-31 March 2020 due seasonal increase in temperature. Due to westerly airmass, the temperature of the northern and north-eastern 
Table 3. $\mathrm{PM}_{2.5}\left(\mu \mathrm{g} \mathrm{m}^{-3}\right)$ concentration over five major cities.

\begin{tabular}{|c|c|c|c|c|}
\hline Year & 2019 (Avg) & 2020 (Avg) & 2019 (Std) & 2020 (Std) \\
\hline \multicolumn{5}{|l|}{ Delhi } \\
\hline March & 72.27 & 53.68 & 22.44 & 20.20 \\
\hline Before 25 March & 71.48 & 59.40 & 31.83 & 18.32 \\
\hline After 25 March & 72.96 & 34.08 & 12.71 & 13.17 \\
\hline \multicolumn{5}{|l|}{ Hyderabad } \\
\hline March & 40.73 & 34.34 & 11.41 & 9.71 \\
\hline Before 25 March & 38.20 & 34.42 & 10.90 & 10.74 \\
\hline After 25 March & 49.40 & 34.09 & 9.06 & 5.46 \\
\hline \multicolumn{5}{|l|}{ Chennai } \\
\hline March & 19.35 & 21.79 & 8.47 & 8.99 \\
\hline Before 25 March & 19.11 & 21.88 & 9.15 & 9.93 \\
\hline After 25 March & 20.17 & 21.50 & 6.09 & 5.11 \\
\hline \multicolumn{5}{|l|}{ Mumbai } \\
\hline March & 52.85 & 46.58 & 17.88 & 18.69 \\
\hline Before 25 March & 51.99 & 48.60 & 18.28 & 20.68 \\
\hline After 25 March & 55.77 & 39.67 & 17.45 & 5.93 \\
\hline \multicolumn{5}{|l|}{ Kolkata } \\
\hline March & 62.82 & 61.15 & 15.45 & 27.82 \\
\hline Before 25 March & 65.57 & 65.55 & 15.45 & 30.22 \\
\hline After 25 March & 53.42 & 46.06 & 12.06 & 4.91 \\
\hline
\end{tabular}

parts of India remain lower, whereas, due to higher temperature in the southern and south eastern parts of India, higher concentration of $\mathrm{HCHO}$ was observed in the southern and south-central India. Lower concentration of $\mathrm{HCHO}$ is observed in the northern, western, and north-western parts of India as temperature is comparatively lower during March. Higher concentration areas are also observed in the north-eastern parts due to forest fires and biomass burning. A decline in the concentrations was observed in 2020 compared with the same periods in the year 2019.

The HCHO concentration was observed to be higher during 22-31 March 2019 (Figs. 3(a) and $3(c))$. An enhancement in $\mathrm{HCHO}$ corresponds to rise in temperature and crop burning activities. During March 2020, due to lockdown, absence, or lower density of road traffic, industrial emissions and crop burning activities, $\mathrm{HCHO}$ concentration decreased in the northern, western, and northwestern parts during 22-31 March 2020 even after rise in temperature. In central, southern, and south-central parts of India, the average concentration is observed to be smaller compared to 2019. So, the effect of lockdown is clearly visible qualitatively during 2020.

We have carried out the analysis of average concentration of column amount $\mathrm{HCHO}$ over five major cities of India during (a) 10-21 March, 2019; (b) 10-21 March, 2020; (c) 22-31 March, 2019 and (d) 22-31 March, 2020 (Fig. 5). In Delhi, the average concentration is observed to be higher during 10-21 March, compared to 22-31 March in both the years. Even highest HCHO concentration is observed during 10-21 March 2020. At the border areas of Delhi, the average concentration was observed to be higher during March this is likely due to the industrial areas located in outer Delhi. The impact of lockdown is clearly observed over Delhi during 22-31 March 2020 since the average concentration is observed to be lower compared to other time periods.

There is no data available during 22-31 March 2019 in the northern parts of Delhi. Kolkata city is in the eastern parts of the Indo-Gangetic Plains and mostly influenced by the westerly airmass during March. An enhancement in $\mathrm{HCHO}$ concentration was observed during lockdown periods (after 21 March until 31 March 2020) in Kolkata, whereas, for the same period in 2019, decline in $\mathrm{HCHO}$ concentration was observed. In Mumbai, enhancement in $\mathrm{HCHO}$ concentration was observed during 22-31 March 2020 compared to 10-21 March 2020. However, when we compared $\mathrm{HCHO}$ for the periods 22-31 March 2019, decline in HCHO concentrations was observed during lockdown period over Mumbai. Similar changes are also observed over Chennai, where decline in $\mathrm{HCHO}$ concentration was observed during 22-31 March 2020 compared to 22-31 March 2019. However, in later half during March (22-31), HCHO concentration was observed to be higher compared to 10-21 March in 2019 and 2020. 

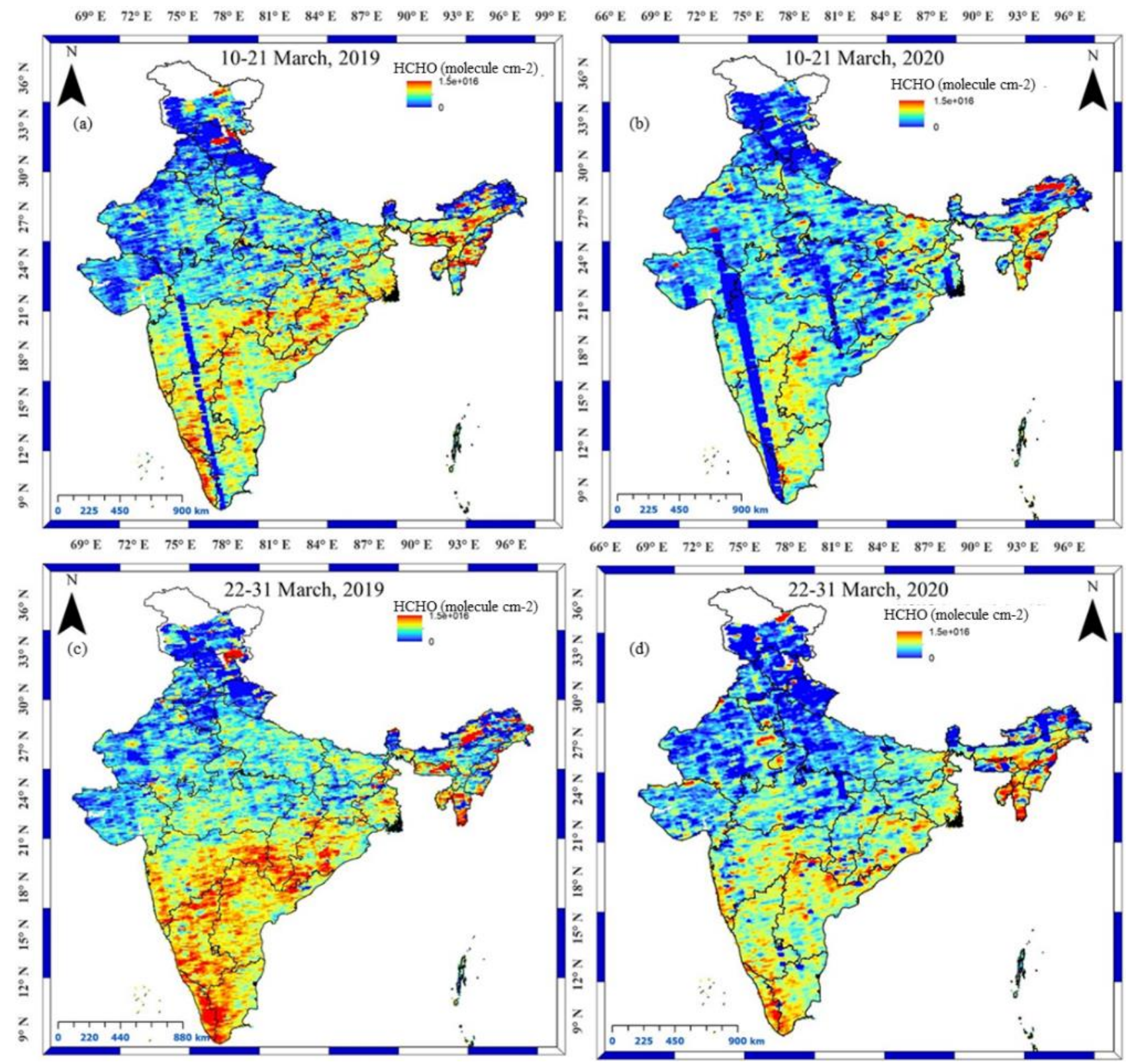

Fig. 4. Spatial variations of column amount of HCHO during (a) 10-21 March 2019; (b) 10-21 March 2020; (c) 22-31 March 2019 and (d) 22-31 March 2020.

In Hyderabad, the average concentration during March 2020 was observed to be higher compared to March 2019, decline in $\mathrm{HCHO}$ concentration was observed due to lockdown. We observed effect of temperature and long-range transport showing higher concentration of $\mathrm{HCHO}$ over Kolkata, Chennai, and Mumbai. In Delhi and Hyderabad, we found slight decline in HCHO concentration, this could be due to influence of long-range transport of westerly and easterly airmass.

\subsection{Tropospheric $\mathrm{NO}_{2}$}

$\mathrm{NO}_{2}$ is a trace gas and its resident time in troposphere is quite short (few hours) which is considered as one of the important key parameters to account for air quality. Singh and Chauhan (2020) carried out analysis of tropospheric $\mathrm{NO}_{2}$ over India during (a) 10-21 March 2019; (b) 1021 March 2020; (c) 22-31 March 2019 and (d) 22-31 March 2020 and found that tropospheric $\mathrm{NO}_{2}$ hotspots are mostly located in the central parts of India where major sources of $\mathrm{NO}_{2}$ are located (coal-based power plants) (Prasad et al., 2006, 2012). The tropospheric $\mathrm{NO}_{2}$ is observed 


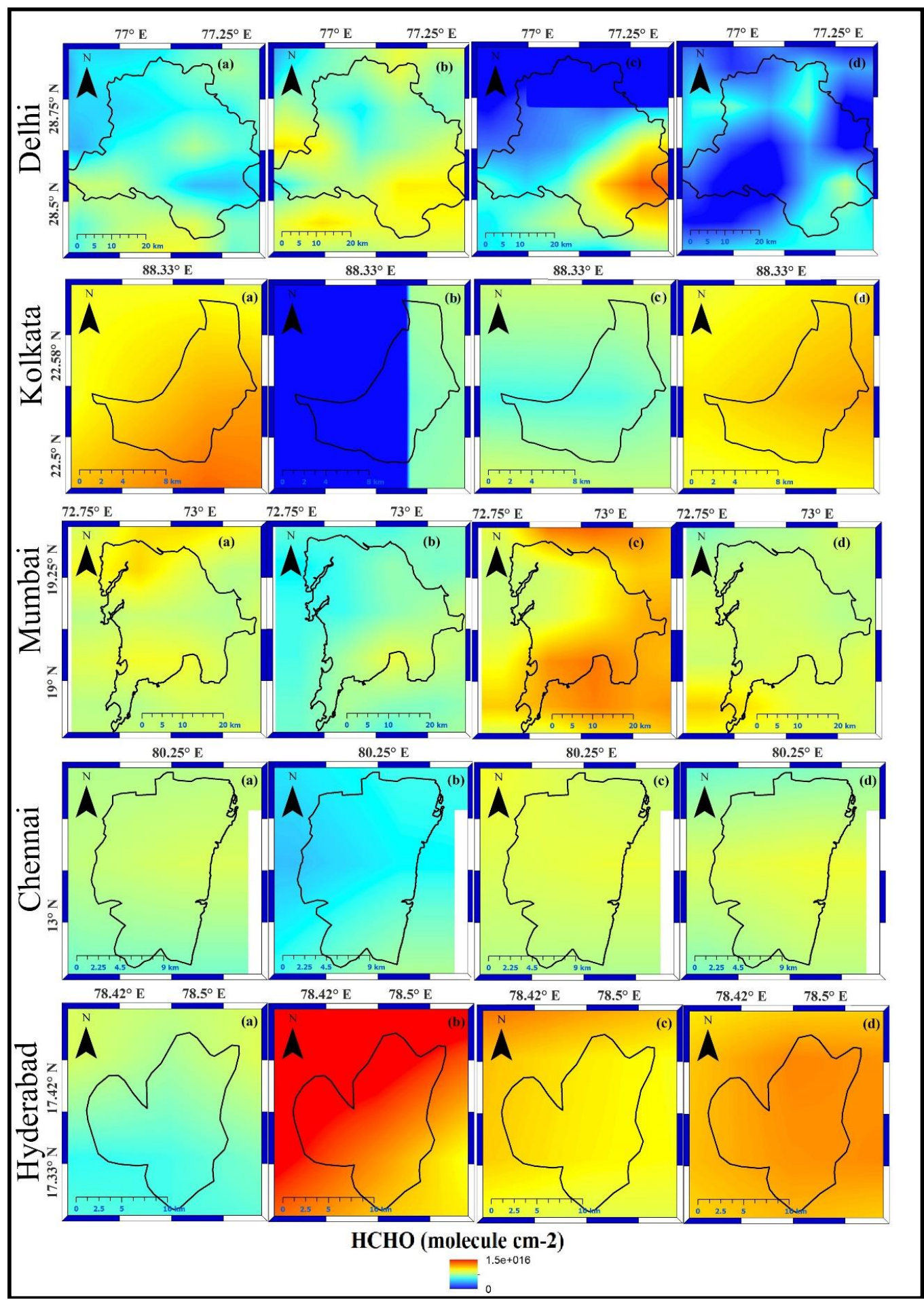

Fig. 5. Spatial average column amount of HCHO over five cities during (a) 10-21 March 2019; (b) 10-21 March 2020; (c) 22-31 March 2019 and (d) 22-31 March 2020.

to be higher in the eastern parts of India where forest fires produce tropospheric $\mathrm{NO}_{2}$ during March. The total lockdown affected mining activities, thus, $\mathrm{NO}_{2}$ concentration was observed to be declined over Jharkhand and Odisha. Further, we have carried out analysis of temporal variations of tropospheric $\mathrm{NO}_{2}$ in major cities of India and compared the results during 2019 and 2020 (Fig. 6). Tropospheric $\mathrm{NO}_{2}$ is also important due to its role in formation of tropospheric ozone. In Delhi, tropospheric $\mathrm{NO}_{2}$ is $1.64 \times 10^{+15} \mathrm{~cm}^{-2}$ during lockdown period 22-31 March 2020 and prior to the lockdown period during $10-21$ March 2020 was $4.31 \times 10^{+15} \mathrm{~cm}^{-2}$, shows decline 


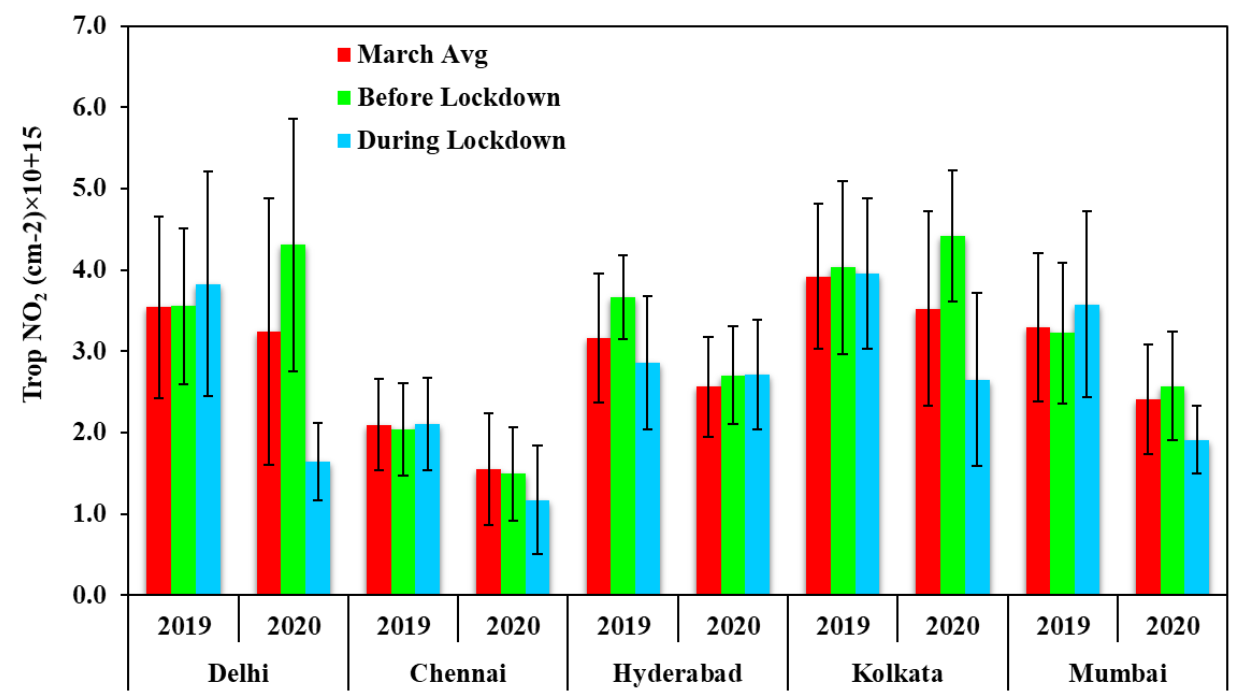

Fig. 6. Average tropospheric $\mathrm{NO}_{2}$ over five cities during (a) March (red bars); (b) before lockdown (green bars) and (c) during lockdown (blue bars).

in $\mathrm{NO}_{2}$ concentrations. Decline of $62 \%$ is observed in tropospheric $\mathrm{NO}_{2}$ concentration after the lockdown in Delhi. For the same time in 2019, $8 \%$ enhancement is observed in tropospheric concentration in Delhi. In Mumbai, the average concentration during 10-21 March 2020 was 2.57 $\times 0^{+15} \mathrm{~cm}^{-2}$ and later during 22-31 March 2020 it was $1.91 \times 10^{+15} \mathrm{~cm}^{-2}$. A total of $26 \%$ decline in tropospheric $\mathrm{NO}_{2}$ concentration is observed in Mumbai. Similarly, in Chennai, a decline of 22\% and in Kolkata, 40\% is observed during 22-31 March 2020 with respect to 10-21 March 2020. In Hyderabad, no change was observed in $\mathrm{NO}_{2}$ concentration during lockdown period. The sudden rise in relative humidity is observed during 20-23 March corresponds with sudden rise in air temperature, that may be the cause of higher $\mathrm{NO}_{2}$ concentration. We have found the average tropospheric $\mathrm{NO}_{2}$ concentration lower during 2020 at all locations compared to 2019.

\subsection{Spatial Distribution of $\mathrm{HCHO} / \mathrm{NO}_{2}$}

Using spatial distribution of $\mathrm{HCHO}$ (Fig. 4) from OMI AURA data and $\mathrm{NO}_{2}$ from OMI AURA data from our earlier studies (Singh and Chauhan, 2020), we have computed ratio of $\mathrm{HCHO} / \mathrm{NO}_{2}$ (Fig. 7). The ratio less than 2 represents the $\mathrm{NO}_{2}$ limited ozone production region and the ratio less than 1 , shows the VOC limited ozone production. The ratio between $1-2$ represents the transition regime where ozone production is sensitive to both $\mathrm{NO}_{2}$ and VOC (Duncan et al., 2010; Chutia et al., 2019). During 10-21 March 2019 ozone production is observed to be sensitive to $\mathrm{NO}_{2}$ in the southern parts of India and in the central, northern, and eastern parts show mostly in transition regime or VOC sensitive, condition is like 2020. During 22-31 March 2019, we observed $\mathrm{NO}_{2}$ sensitive regions over the western, central and north-eastern parts, mostly in transition regime. During 22-31 March 2020, the western, central, and north-eastern parts shows VOC limited or in transition regions.

\subsection{Change in $\mathrm{SO}_{2}$}

In Fig. 8, we have shown the spatial distribution of average $\mathrm{SO}_{2}$ (planetary boundary layer). During March 2019, higher $\mathrm{SO}_{2}$ concentration was observed over the central, southern, and western parts of India. The coal mining region of the Jharkhand state (in the eastern parts of the Indo-Gangetic plains) was seen distinctively with higher $\mathrm{SO}_{2}$ concentration that observed to increase in the southern parts of India during 22-31 March 2019. During 10-21 March 2020, $\mathrm{SO}_{2}$ concentration was observed to be higher over Jharkhand, Odisha and in the northern parts of India in comparison to 2019. A pronounced decrease in $\mathrm{SO}_{2}$ concentration was observed during lockdown period 22-31 March 2020 over major parts of India. This time sudden rise in $\mathrm{SO}_{2}$ concentration was observed over Rajasthan and Punjab (states) (north western parts), but during 2019 it was not observed. The higher $\mathrm{SO}_{2}$ concentration was observed in this region due to the 


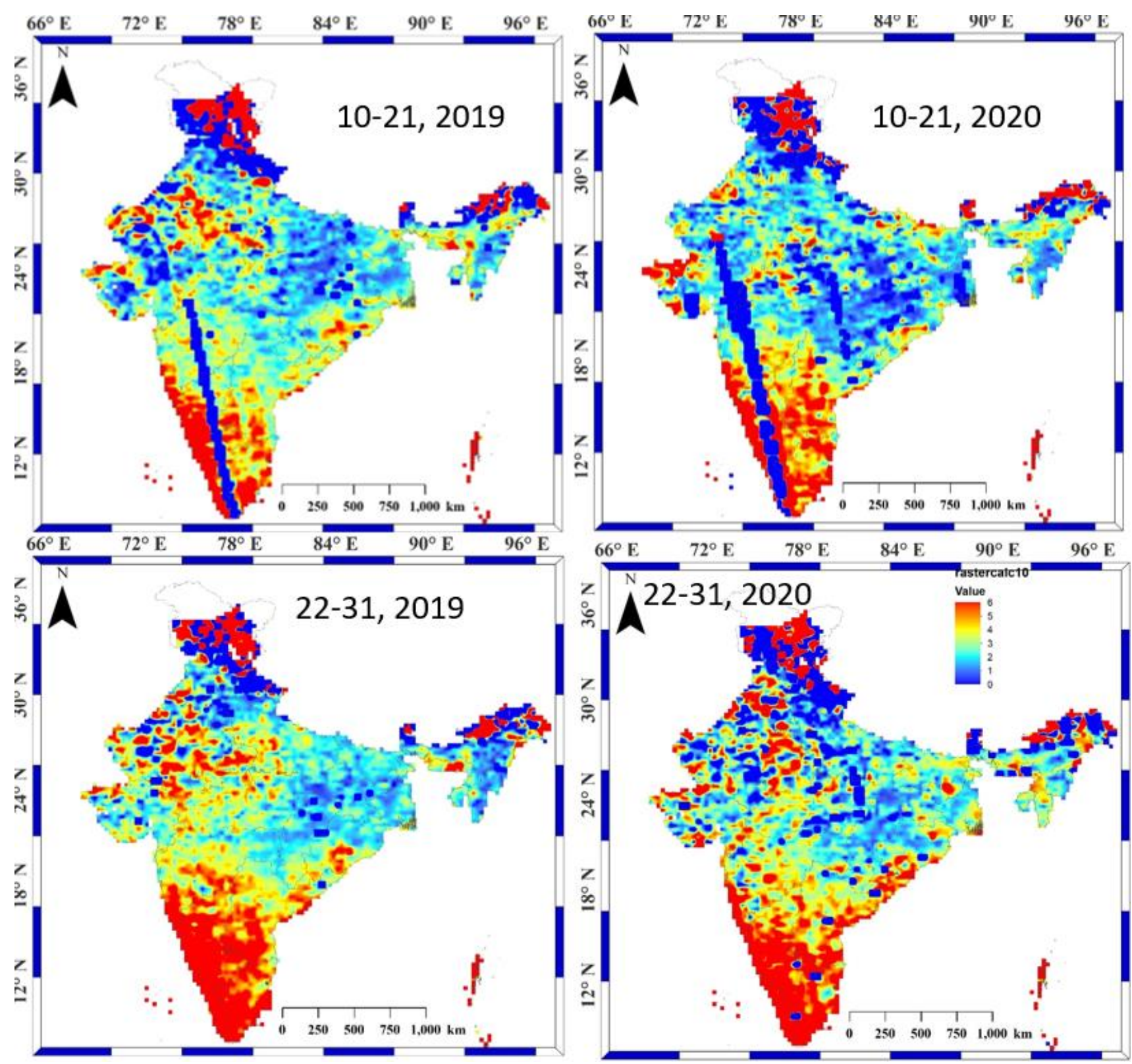

Fig. 7. Spatial distribution of $\mathrm{HCHO} / \mathrm{NO}_{2}$ ratio over India during pre (10-21 March 2020 and similar periods in 2019 and during lockdown period 22-31 March 2020 and for the same period in 2019 for comparison.

long-range transport of airmass from Punjab province of Pakistan side associated with the westerly winds.

The $\mathrm{SO}_{2}$ concentration was observed to be higher during March in Punjab province of Pakistan (Khattak et al., 2014) associated with the coal based power plants located in Pakistan.

\subsection{Change in Methane Concentration}

Methane is one of major greenhouse gases in the atmosphere, next to $\mathrm{CO}_{2}$. We have carried out analysis of methane at $925 \mathrm{hPa}$ (Fig. 9). An enhancement in methane concentration was observed in Delhi and Kolkata and in the Indo-Gangetic plains, whereas decline in methane concentration was observed during lockdown period in 2020 over Hyderabad, Chennai, and Mumbai.

In Delhi, an average methane concentration was observed to be lower (1861 ppbv) during March 2020 compared to March 2019 (1871 ppbv). During 22-30 March 2019, the average concentration was lower with respect to 10-21 March 2019 and in 2020, enhancement was observed in $\mathrm{CH}_{4}$ concentration during lockdown period. In Kolkata, the average concentration as 


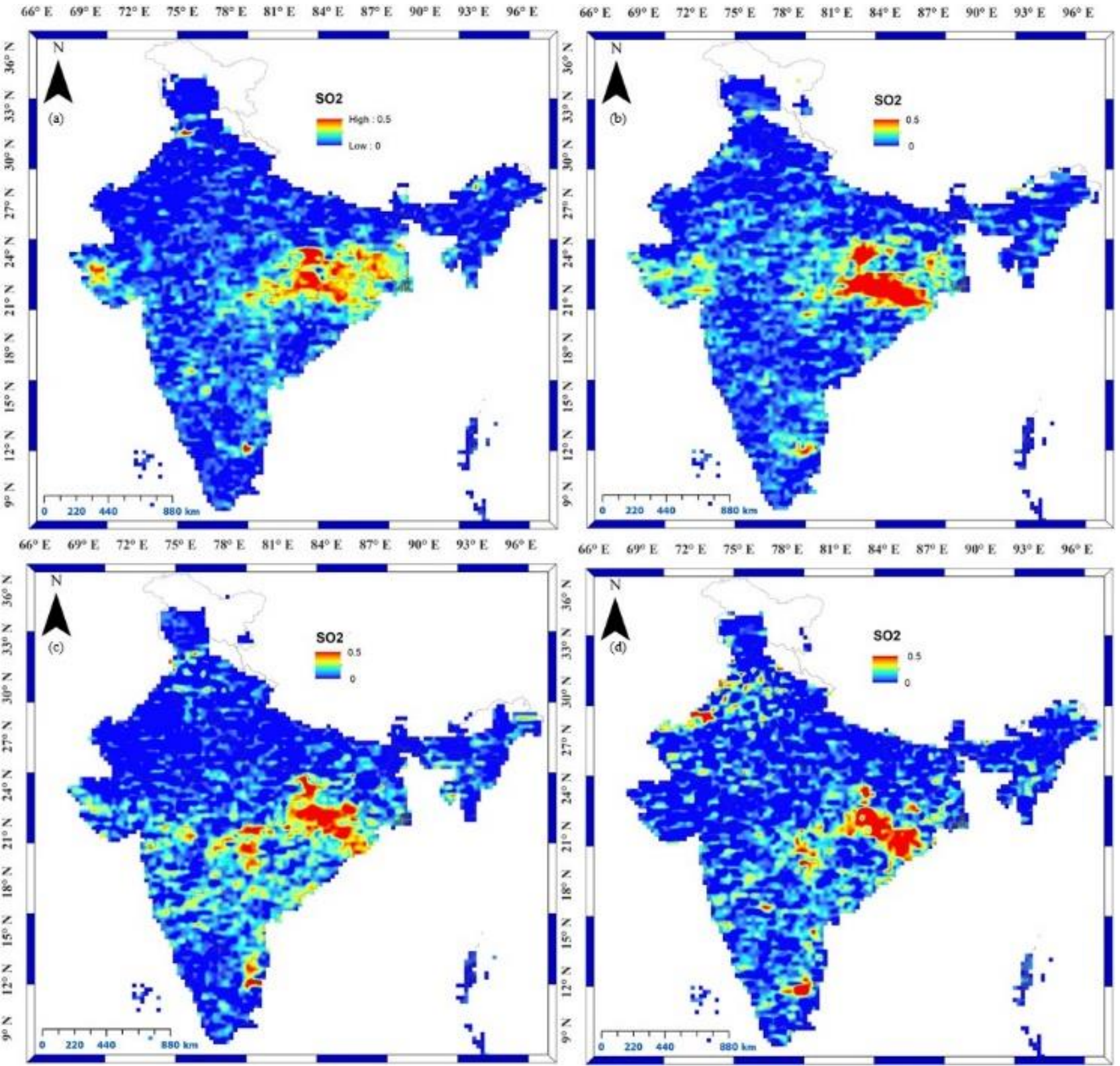

Fig. 8. Spatial variations of $\mathrm{SO}_{2}$ (pbl) over India during (a) 10-21 March 2019; (b) 10-21 March 2020; (c) 22-31 March 2019 and (d) 22-31 March 2020.

well as concentration during lockdown, both are found to be higher compared to 2019 and before lockdown period. In Chennai, average enhancement in methane concentration was observed to be small but after 22 March 2020 concentration was declined. In Hyderabad, decline was observed in the average value of March 2020 compared to 2019 and during lockdown period, sudden decline was observed in methane concentration. In Mumbai, an increase in average concentration was observed during March 2020 but decline in the average concentration during 22-31, March 2020 during lockdown period. The methane concentration shows no major direct relationship with decline in anthropogenic activities due to its longer residential time and emission due natural sources.

In Fig. 10, we have shown the average CO concentration over five major cities of India during March 2019 and 2020. In Delhi, the average CO concentration was higher during March 2020 and decline during the lockdown period. In Chennai, an increase in CO concentration was observed during March 2020 but decline in CO concentration during lockdown period. In Hyderabad, the results are like Chennai city. But in Kolkata the average $\mathrm{CO}$ concentration was like those during 


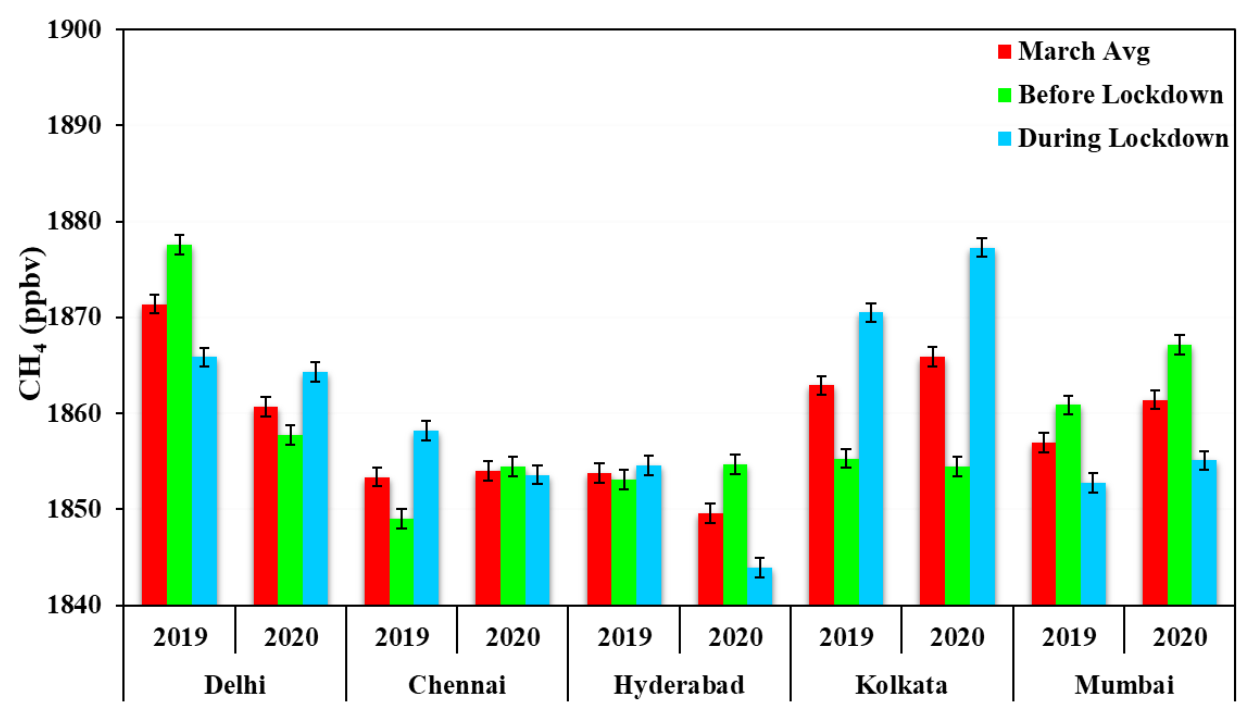

Fig. 9. Average methane concentrations at $925 \mathrm{hPa}$ over five cities during (a) March (red bars); (b) before lockdown (10-21 March) (green bars) and (c) during lockdown (22-31 March) (blue bars).

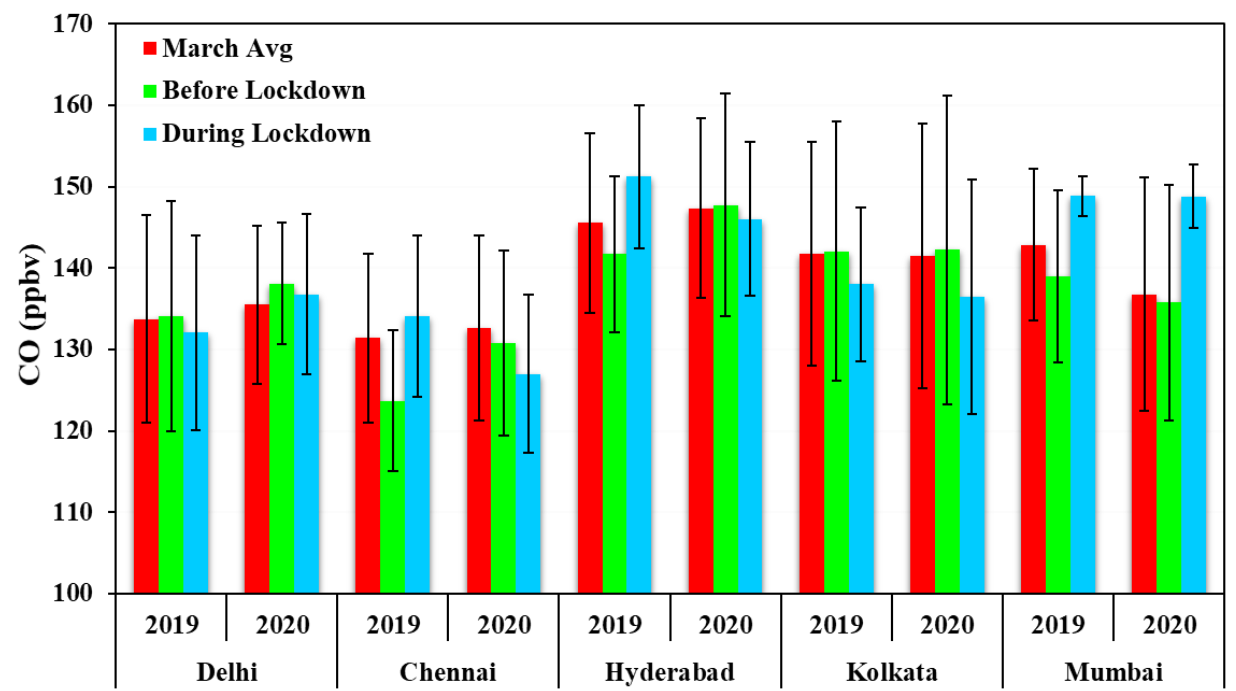

Fig. 10. Average $\mathrm{CO}$ at $925 \mathrm{hPa}$ over five cities during (a) March (red bars); (b) before lockdown (green bars) and (c) during lockdown (blue bars).

2019 and sudden decline in CO concentration during lockdown period. In Mumbai, an increase in $\mathrm{CO}$ concentration during lockdown period.

The effect of the lockdown was observed over the ozone concentration at the pressure level $925 \mathrm{hPa}$ close to the surface (Fig. 11). In Delhi, decline in Ozone concentration up to $6.93 \%$ during 22-31 March 2020, whereas, during similar days, an increase of 2.33\% in Delhi was observed. In Kolkata and Mumbai, there is an enhancement of $1.81 \%$ and $0.24 \%$, respectively during $22-31$ March 2020 but Chennai and Hyderabad show rise in Ozone concentration of .87\% and .11\%. On comparing 2019 and 2020 results, the average concentration is observed to be higher in Delhi, Kolkata and Mumbai but Hyderabad and Chennai a slight increase in 2020 was observed compared to 2019. Atmospheric chemistry and meteorology play quite important role over Chennai and Hyderabad, we observe rise in $\mathrm{HCHO}$ concentration due to higher temperature in comparison to other cities that may play role in enhancement in slight enhancement in ozone concentration. Also, we found time lag in methane and ozone concentrations. The increase in $\mathrm{CH}_{4}$ concentration during 10-21 March, is likely to cause rise in ozone concentration during 22-31 March. But no 


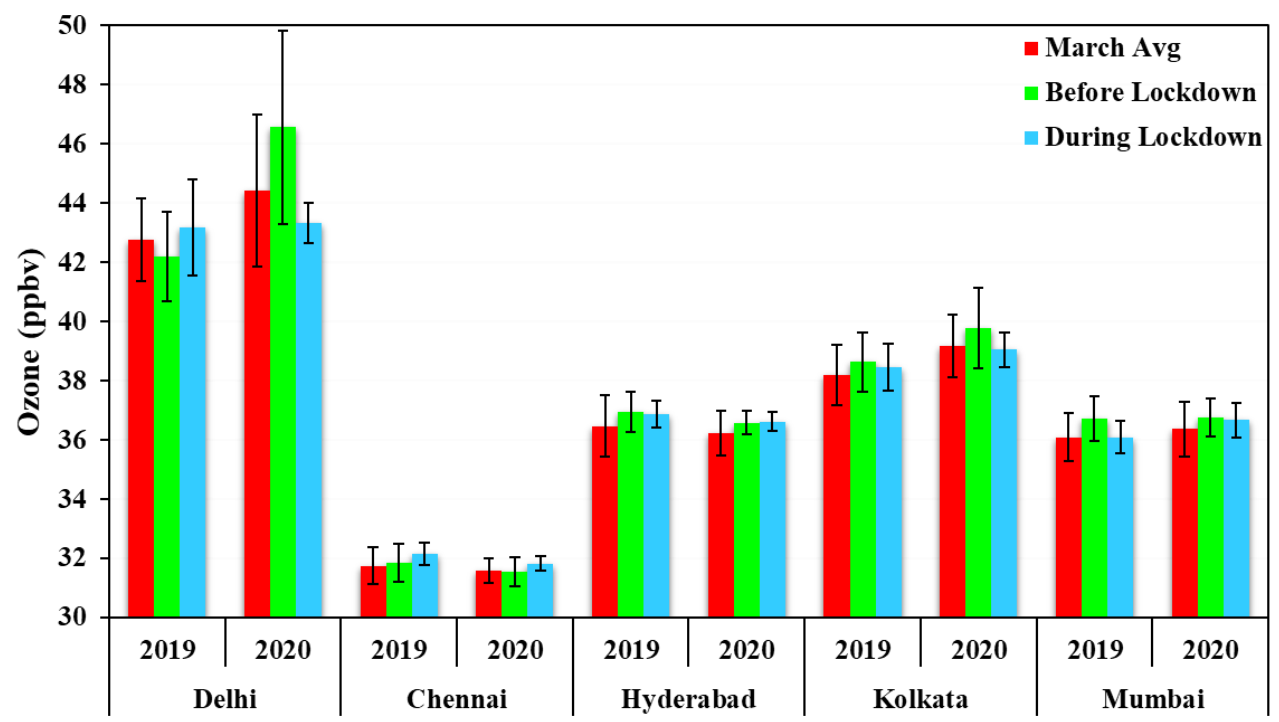

Fig. 11. Average Ozone at $925 \mathrm{hPa}$ over five cities during (a) March (red bars); (b) before lockdown (green bars) and (c) during lockdown (blue bars).

time lag is observed over Mumbai, as higher ozone concentration with higher $\mathrm{CH}_{4}$ concentration. But no direct correlation is observed in $\mathrm{CO}$ and ozone concertation.

These results show pronounced changes in concentration of various gases during lockdown period over India due to decline in anthropogenic activities and change in meteorology. Our results during lockdown periods will be useful to the atmospheric modelling and climate community to evaluate radiative budget and long-term changes in India and over Asian countries.

\section{CONCLUSION}

During lockdown, major sources of atmospheric pollutants were either completely closed or partially open, thus, pronounced changes in various trace gases ( $\mathrm{HCHO}, \mathrm{NO}_{2}, \mathrm{SO}_{2}, \mathrm{CH}_{4}$ and $\mathrm{CO}$ ) were observed. During lockdown, natural source along with few anthropogenic activities like crop burning, power plants played an important role. In Delhi, Kolkata, Mumbai, and Hyderabad sudden decline in $\mathrm{PM}_{2.5}$ concentration was observed. But no major changes were observed in Chennai. $\mathrm{HCHO}$ concentration was decreased in major parts of India but the enhancement in temperature helped in rising $\mathrm{HCHO}$ concentration in the southern and eastern parts of India. The tropospheric $\mathrm{NO}_{2}$ was seen to be decreased at Delhi, Mumbai, Kolkata, and Chennai during lockdown period and it is lower than those in 2019. Over Hyderabad no decline is observed during 2020 but average $\mathrm{NO}_{2}$ concertation in 2020 is observed to be lower compared to 2019 during lockdown period. Decline in total column $\mathrm{SO}_{2}$ was observed in major parts of India but Rajasthan and Punjab region (the north western parts) show some enhancement due to long range transport of airmass from Pakistan region. Some of the areas show enhancement in the concentration due to the crop residue burning and dust events. Similarly, we observed change in concentration in $\mathrm{CH}_{4}, \mathrm{CO}$ and ozone during lockdown period and but methane concentration show no pronounced changes due to its longer residential time in atmosphere. The $\mathrm{CO}$ concentration is also affected by the anthropogenic activity and decline is observed during lockdown period. We observed a time lag in ozone and $\mathrm{CH}_{4}$ concentration at the pressure level $925 \mathrm{hPa}$ over these cities as higher $\mathrm{CH}_{4}$ before the 21 March caused higher ozone concentration after 21 March. These results show that these trace gases are not only depended over the anthropogenic activities, but also dependent on natural processes and long-range transport and the winds play an important role in bringing pollutants from the rural areas to metro cities. Among all the major pollutants, particulate matter concentration and $\mathrm{NO}_{2}$ show the most significant decline in India during lockdown. $\mathrm{SO}_{2}$ and $\mathrm{CO}$ show moderate decline but due to some influential factors like crop residue burning, dust and long-range transport of pollutants from neighbouring countries, the decline is comparatively lesser in $\mathrm{NO}_{2}$. 
Similarly, $\mathrm{CH}_{4}$ and $\mathrm{O}_{3}$ are also influenced by the lockdown due to lesser anthropogenic emissions but these changes are less significant due to their longer resident time and influenced by secondary pollutants.

\section{ADDITIONAL INFORMATION}

\section{Authorship Contribution Statement}

Ramesh P Singh: Conceptualization and writing review and editing, Akshansha Chauhan: Data curation, Software, original draft, Writing and finalization of manuscript.

\section{Declaration of Competing Interest}

The authors declare that they have no known competing financial interests or personal relationships that could have appeared to influence the work reported in this paper.

\section{Data Availability Statement}

All the data used in the present study are freely available through NASA Giovanni portal; if needed, we will provide the data used in the present study to anyone.

\section{ACKNOWLEDGMENTS}

The authors thank NASA Giovanni team for providing AIRS data through NASA Giovanni portal. We are also grateful to the Akash project lead by Sachiko Sachiko Hayashida (Japan) and all the team members from India and Japan for useful discussion during July 2020 online meeting of the project. Our thanks to two anonymous Referees for their comments/suggestions which have helped us to improve earlier version of the manuscript.

\section{REFERENCES}

Arif, M., Kumar, R., Kumar, R., Zusman, E., Singh, R.P., Gupta, A. (2018). Assessment of indoor \& outdoor black carbon emissions in rural areas of Indo-Gangetic Plain: Seasonal characteristics, source apportionment and radiative forcing. Atmos. Environ. 191, 227-240. https://doi.org/1 0.1016/j.atmosenv.2018.07.057

Badarinath, K.V.S., Kiran Chand, T.R., Krishna Prasad, V. (2009). Emissions from grassland burning in Kaziranga National Park, India-analysis from IRS-P6 AWiFS satellite remote sensing datasets. Geocarto Int. 24, 89-97. https://doi.org/10.1080/10106040701207225.

Bhattacharjee, P.S., Prasad, A.K., Kafatos, M., Singh, R.P. (2007). Influence of a dust storm on carbon monoxide and water vapor over the Indo-Gangetic Plains. J. Geophys. Res. 112, D18203. https://doi.org/10.1029/2007JD008469

Burkholder, J.B., Sander, S.P., Abbatt, J.P.D., Barker, J.R., Huie, R.E., Kolb, C.E., Kurylo, M.J., Orkin, V.L., Wilmouth, D.M., Wine, P.H. (2015). Chemical kinetics and photochemical data for use in atmospheric studies: Evaluation number 18. Pasadena, CA: Jet Propulsion Laboratory, National Aeronautics and Space. https://doi.org/10.13140/RG.2.1.2504.2806

Chauhan, A., Singh, R.P. (2017). Poor air quality and dense haze/smog during 2016 in the indogangetic plains associated with the crop residue burning and diwali festival, in: 2017 IEEE International Geoscience and Remote Sensing Symposium (IGARSS), Presented at the 2017 IEEE International Geoscience and Remote Sensing Symposium (IGARSS), pp. 6048-6051. https://doi.org/10.1109/IGARSS.2017.8128389

Chauhan, A., Singh, R.P., (2020). Decline in $\mathrm{PM}_{2.5}$ concentrations over major cities around the world associated with COVID-19. Environ. Res. 187, 109634. https://doi.org/10.1016/j.envres. 2020.109634

Chutia, L., Ojha, N., Girach, I.A., Sahu, L.K., Alvarado, L.M.A., Burrows, J.P., Pathak, B., Bhuyan, P.K. (2019). Distribution of volatile organic compounds over Indian subcontinent during winter: WRF-chem simulation versus observations. Environ. Pollut. 252, 256-269. https://doi.org/10. 1016/j.envpol.2019.05.097 
Dasgupta, P.K., Li, J., Zhang, G., Luke, W.T., McClenny, W.A., Stutz, J., Fried, A. (2005). Summertime ambient formaldehyde in five US metropolitan areas: Nashville, Atlanta, Houston, Philadelphia, and Tampa. Environ. Sci. Technol. 39, 4767-4783. https://doi.org/10.1 021/es048327d

Dimri, A.P., Chevuturi, A. (2016). Western Disturbances - Indian Seasons, in: Dimri, A.P., Chevuturi, A. (Eds.), Western Disturbances - An Indian Meteorological Perspective, Springer International Publishing, Cham, pp. 61-82. https://doi.org/10.1007/978-3-31926737-1_3

Duncan, B.N., Yoshida, Y., Olson, J.R., Sillman, S., Martin, R.V., Lamsal, L., Hu, Y.T., Pickering, K.E., Retscher, C., Allen, D.J., Crawford, J.H. (2010). Application of OMI observations to a spacebased indicator of $\mathrm{NO}_{\mathrm{x}}$ and $\mathrm{VOC}$ controls on surface ozone formation. Atmos. Environ. 44, 2213-2223. https://doi.org/10.1016/jatmosenv.2010.03.010

Garg, V., Aggarwal, S.P., Chauhan, P. (2020). Changes in turbidity along Ganga River using Sentinel-2 satellite data during lockdown associated with COVID-19. Geomatics, Nat. Hazards Risk 11, 1175-1195. https://doi.org/10.1080/19475705.2020.1782482

Ghosh, D., Sarkar, U., De, S. (2015), Analysis of ambient formaldehyde in the eastern region of India along Indo-Gangetic Plain. Environ Sci Pollut Res. 22, 18718-18730. https://doi.org/10.10 07/s11356-015-5029-y

Gogoi, M.M., Babu, S.S., Moorthy, K.K., Bhuyan, P.K., Pathak, B., Subba, T., Chutia, L., Kundu, S.S., Bharali, C., Borgohain, A., Guha, A. (2017). Radiative effects of absorbing aerosols over northeastern India: Observations and model simulations. J. Geophys. Res. 122, 1132-1157. https://doi.org/10.1002/2016JD025592

Goldan, P.D., Parrish, D.D., Kuster, W.C., Trainer, M., McKeen, S.A., Holloway, J., Jobson, B.T., Sueper, D.T., Fehsenfeld, F.C. (2000). Airborne measurements of isoprene, CO, and anthropogenic hydrocarbons and their implications. J. Geophys. Res. 105, 9091-9105. https://doi.org/10.1029/1999JD900429

Gupta, S., Raghuwanshi, G.S., Chanda, A. (2020). Effect of weather on COVID-19 spread in the US: A prediction model for India in 2020. Sci. Total Environ. 728, 138860. https://doi.org/10.1016/ j.scitotenv.2020.138860

Guttikunda, S.K., Goel, R., Pant, P. (2014). Nature of air pollution, emission sources, and management in the Indian cities. Atmos. Environ. 95, 501-510. https://doi.org/10.1016/j.atmo senv.2014.07.006

Karar, K., Gupta, A.K. (2006). Seasonal variations and chemical characterization of ambient PM 10 at residential and industrial sites of an urban region of Kolkata (Calcutta), India. Atmos. Res. 81, 36-53. https://doi.org/10.1016/j.atmosres.2005.11.003

Khattak, P., Khokhar, M.F., Yasmin, N. (2014). Spatio-temporal analyses of atmospheric sulfur dioxide column densities over Pakistan by using SCIAMACHY data. Aerosol Air Qual. Res. 14, 1883-1896. https://doi.org/10.4209/aaqr.2013.12.0357

Kumar, D.B., Verma, S. (2016). Potential emission flux to aerosol pollutants over Bengal Gangetic plain through combined trajectory clustering and aerosol source fields analysis. Atmos. Res. 178, 415-425. https://doi.org/10.1016/j.atmosres.2016.04.012

Kumar, S., Kumar, S., Kaskaoutis, D.G., Singh, R.P., Singh, R.K., Mishra, A.K., Srivastava, M.K., Singh, A.K. (2015). Meteorological, atmospheric and climatic perturbations during major dust storms over Indo-Gangetic Basin. Aeolian Res. 17, 15-31. https://doi.org/10.1016/j.aeolia.201 5.01 .006

Kumari, P., Toshniwal, D. (2020). Impact of lockdown measures during COVID-19 on air quality-A case study of India. Int. J. Environ. Health Res. https://doi.org/10.1080/09603123.2020.1778646

Li, M., Zhang, Q., Streets, D.G., He, K.B., Cheng, Y.F., Emmons, L.K., Huo, H., Kang, S.C., Lu, Z., Shao, M. (2014). Mapping Asian anthropogenic emissions of non-methane volatile organic compounds to multiple chemical mechanisms. Atmos. Chem. Phys 14, 5617-5638. https://doi.org/10.5194/acp-14-5617-2014

Mahato, S., Pal, S., Ghosh, K.G. (2020). Effect of lockdown amid COVID-19 pandemic on air quality of the megacity Delhi, India. Sci. Total Environ. 730, 139086. https://doi.org/10.1016/j.scitote nv.2020.139086

Majumdar, D., Mukherjee, A.K., Sen, S. (2011). BTEX in ambient air of a Metropolitan City. J. Environ. Protection 2, 11-20. https://doi.org/10.4236/jep.2011.21002 
Middleton, N.J. (1986). A geography of dust storms in South-west Asia. J. Climatol 6, 183-196. https://doi.org/10.1002/joc.3370060207

Miller, S.M., Matross, D.M., Andrews, A.E., Millet, D.B., Longo, M., Gottlieb, E.W., Hirsch, A.I., Gerbig, C., Lin, J.C., Daube, B.C. (2008). Sources of carbon monoxide and formaldehyde in North America determined from high-resolution atmospheric data. Atmos. Chem. Phys. 8, 7673-7696. https://doi.org/10.5194/acp-8-7673-2008

Mittal, M.L., Sharma, C., Singh, R. (2012). Estimates of emissions from coal fired thermal power plants in India. 2012 International Emission Inventory Conference. 2012. p. 13-16.

Mittal, S.K., Singh, N., Agarwal, R., Awasthi, A., Gupta, P.K. (2009). Ambient air quality during wheat and rice crop stubble burning episodes in Patiala. Atmos. Environ 43, 238-244. https://doi.org/10.1016/j.atmosenv.2008.09.068

Ojha, N., Naja, M., Singh, K.P., Sarangi, T., Kumar, R., Lal, S., Lawrence, M.G., Butler, T.M., Chandola, H.C. (2012). Variabilities in ozone at a semi-urban site in the Indo-Gangetic Plain region: association with the meteorology and regional process. J. Geophys. Res. 117, D20301. https://doi.org/10.1029/2012JD017716

Pathak, B., Subba, T., Dahutia, P., Bhuyan, P.K., Moorthy, K.K., Gogoi, M.M., Babu, S.S., Chutia, L., Ajay, P., Biswas, J., Bharali, C. (2016). Aerosol characteristics in north-east India using ARFINET spectral optical depth measurements. Atmos. Environ. 125, 461-473. https://doi.org/10.1016/ j.atmosenv.2015.07.038

Prasad, A.K., Singh, R.P. (2007). Changes in aerosol parameters during major dust storm events (2001-2005) over the Indo-Gangetic Plains using AERONET and MODIS data. J. Geophys. Res. 112, D09208. https://doi.org/10.1029/2006JD007778

Prasad, A.K., Singh, R.P., Kafatos, M. (2012). Influence of coal-based thermal power plants on the spatial-temporal variability of tropospheric $\mathrm{NO}_{2}$ column over India. Environ. Monit. Assess. 184, 1891-1907. https://doi.org/10.1007/s10661-011-2087-6

Prasad, A.K., Singh, R.P., Kafatos, M. (2006). Influence of coal based thermal power plants on aerosol optical properties in the Indo-Gangetic basin. Geophys. Res. Lett. 33, L05805. https://doi.org/10.1029/2005GL023801

Priyadharshini, B., Verma, S., Chatterjee, A., Sharma, S.K., Mandal, T.K. (2019). Chemical characterization of fine atmospheric particles of water-soluble ions and carbonaceous species in a tropical urban atmosphere over the Eastern Indo-Gangetic Plain. Aerosol Air Qual. Res. 19, 129-147. https://doi.org/10.4209/aaqr.2017.12.0606

Priyadharshini, B., Verma, S., Giles, D.M., Holben, B.N. (2018). Discerning the premonsoon urban atmosphere aerosol characteristic and its potential source type remotely sensed by AERONET over the Bengal Gangetic plain. Environ. Sci. Pollut. Res. Int. 25, 22163-22179. https://doi.org/ 10.1007/s11356-018-2290-x

Rajbhandari, B., Phuyal, N., Shrestha, B., Thapa, M. (2020). Air Medical Evacuation of Nepalese Citizen During Epidemic of COVID-19 from Wuhan to Nepal. J. Nepal Med. Assoc. 58. https://doi.org/10.31729/jnma.4857

Ramachandra, T. V, Aithal, B.H., Sreejith, K. (2015). GHG footprint of major cities in India. Renewable Sustainable Energy Rev. 44, 473-495. https://doi.org/10.1016/j.rser.2014.12.036

Sahu, L.K., Sheel, V., Pandey, K., Yadav, R., Saxena, P., Gunthe, S. (2015). Regional biomass burning trends in India: Analysis of satellite fire data. J. Earth Syst. Sci. 124, 1377-1387. https://doi.org/10.1007/s12040-015-0616-3

Sarkar, S., Chauhan, A., Kumar, R., Singh, R.P. (2019). Impact of deadly dust storms (May 2018) on air quality, meteorological, and atmospheric parameters over the northern parts of India. GeoHealth 3, 67-80. https://doi.org/10.1029/2018GH000170

Sarkar, S., Singh, R.P., Chauhan, A. (2018a). Crop residue burning in northern India: Increasing threat to greater India. J. Geophys. Res. 123, 6920-6934. https://doi.org/10.1029/2018JD028428

Sarkar, S., Singh, R.P., Chauhan, A. (2018b). Increasing health threat to greater parts of India due to crop residue burning. Lancet Planetary Health 2, e327-e328. https://doi.org/10.1016/S25425196(18)30166-9

Seinfeld, J.H., Pandis, S.N. (2006). Atmospheric chemistry and physics: From Air Pollution to climate change, second ed. John Wiley \& Sons, New York. https://doi.org/10.1063/1.882420

Selvam, S., Muthukumar, P., Venkatramanan, S., Roy, P.D., Bharath, K.M., Jesuraja, K. (2020). SARS-CoV-2 pandemic lockdown: Effects on air quality in the industrialized Gujarat state of 
India. Sci. Total Environ. 737, 140391. https://doi.org/10.1016/j.scitotenv.2020.140391

Sharma, S., Zhang, M., Gao, J., Zhang, H., Kota, S.H. (2020). Effect of restricted emissions during COVID-19 on air quality in India. Sci. Total Environ 728, 138878. https://doi.org/10.1016/j.scito tenv.2020.138878

Singh, H., Chen, Y., Tabazadeh, A., Fukui, Y., Bey, I., Yantosca, R., Jacob, D., Arnold, F., Wohlfrom, K., Atlas, E. (2000). Distribution and fate of selected oxygenated organic species in the troposphere and lower stratosphere over the Atlantic. J. Geophys. Res. 105, 3795-3805. https://doi.org/10.1029/1999JD900779

Singh, R.P. (2014). Dust Storms and Their Influence on Atmospheric Parameters over the IndoGangetic Plains, in: Sundaresan, J., Santosh, K.M., Déri, A., Roggema, R., Singh, R. (Eds.), Geospatial Technologies and Climate Change, Springer International Publishing, Cham, pp. 2135. https://doi.org/10.1007/978-3-319-01689-4_2

Singh, R.P., Chauhan, A. (2020). Impact of lockdown on air quality in India during COVID-19 pandemic. Air Qual. Atmos. Health 13, 921-928. https://doi.org/10.1007/s11869-020-00863-1

Singh, R.P., Kaskaoutis, D.G. (2014). Crop residue burning: a threat to South Asian air quality. Eos, Trans. Am. Geophys. Union 95, 333-334. https://doi.org/10.1002/2014EO370001

Smith, K.R., Aggarwal, A.L., Dave, R.M. (1983). Air pollution and rural biomass fuels in developing countries: A pilot village study in India and implications for research and policy. Atmos. Environ. 17, 2343-2362. https://doi.org/10.1016/0004-6981(83)90234-2

Streets, D.G., Yarber, K.F., Woo, J., Carmichael, G.R. (2003). Biomass burning in Asia: Annual and seasonal estimates and atmospheric emissions. Global Biogeochem. Cycles 17, 1099. https://doi.org/10.1029/2003GB002040

Talapatra, A., Srivastava, A. (2011). Ambient air non-methane volatile organic compound (NMVOC) study initiatives in India-A review. J. Environ. Prot. 2, 21. https://doi.org/10.4236/je p.2011.21003

U.S. Environmental Protection Agency (U.S. EPA) (2003) In: Formaldehyde: hazard summary, https://archive.epa.gov/region5/teach/web/pdf/formaldehyde_summary.pdf

Verma, S., Reddy, D.M., Ghosh, S., Kumar, D.B., Chowdhury, A.K. (2017). Estimates of spatially and temporally resolved constrained black carbon emission over the Indian region using a strategic integrated modeling approach. Atmos. Res. 195, 9-19. https://doi.org/10.1016/j.atm osres.2017.05.007

Wallace, J.M., Hobbs, P.V. (2006). Atmospheric science: An introductory survey. Elsevier. https://doi.org/10.1016/j.atmosres.2017.05.007

Wang, C., Horby, P.W., Hayden, F.G., Gao, G.F. (2020a). A novel coronavirus outbreak of global health concern. Lancet 395, 470-473. https://doi.org/10.1016/S0140-6736(20)30185-9

Wang, L., Li, J., Guo, S., Xie, N., Yao, L., Cao, Y., Day, S.W., Howard, S.C., Graff, J.C., Gu, T., Ji, J., Gu, W., Sun, D. (2020b). Real-time estimation and prediction of mortality caused by COVID-19 with patient information based algorithm. Sci. Total Environ. 727, 138394. https://doi.org/10.1 016/j.scitotenv.2020.138394

Wang, L.S., Wang, Y.R., Ye, D.W., Liu, Q.Q. (2020c). A review of the 2019 Novel Coronavirus (COVID-19) based on current evidence. Int. J. Antimicrob. Agents 55, 105948. https://doi.org/ 10.1016/j.ijantimicag.2020.105948

Wang, P., Chen, K., Zhu, S., Wang, P., Zhang, H. (2020d). Severe air pollution events not avoided by reduced anthropogenic activities during COVID-19 outbreak. Resour. Conserv. Recycl. 158, 104814. https://doi.org/10.1016/j.resconrec.2020.104814

World Health Organization (WHO) (1999) International Programme on Chemical Safety. https://www.who.int/ipcs/publications/ehc/ehc_numerical/en/

Zheng, S., Singh, R.P., Wu, Y., Wu, C. (2017). A comparison of trace gases and particulate matter over Beijing (China) and Delhi (India). Water, Air, Soil Pollut 228, 181. https://doi.org/10.1007/ s11270-017-3360-2 